\title{
Morphological and morphometric variability of the squid Lolliguncula brevis (Mollusca: Cephalopoda) in brazilian waters: evidence for two species in the western atlantic?
}

\author{
TÂNIA ZALESKI ${ }^{1}$, JOSÉ A. ANGEL PEREZ ${ }^{2}$ and ANA LUIZA GANDARA-MARTINS ${ }^{3}$ \\ ${ }^{1}$ Programa de Pós-Graduação em Ecologia e Conservação (PPG-ECO), Universidade Federal do Paraná, \\ Setor de Ciências Biológicas, Centro Politécnico, Jardim das Américas, 81531-980 Curitiba, PR, Brasil \\ ${ }^{2}$ Centro de Ciências Tecnológicas da Terra e do Mar, Universidade do Vale do Itajaí, \\ Rua Uruguai, 458, Centro, Caixa Postal, 360, 88302-202 Itajaí, SC, Brasil \\ ${ }^{3}$ Programa de Pós-Graduação em Sistemas Costeiros e Oceânicos, Centro de Estudos do Mar, \\ Universidade Federal do Paraná (UFPR), Av. Beira Mar, s/n, 83255-000 Pontal do Paraná, PR, Brasil
}

Manuscript received on July 7, 2011; accepted for publication on October 28, 2011

\begin{abstract}
Morphological and morphometric variability of the small-sized coastal squid Lolliguncula brevis was assessed along the largest part of its latitudinal range in the southern hemisphere, off the Brazilian coast $\left(8^{\circ} \mathrm{S}-27^{\circ} \mathrm{S}\right)$. A general homogeneity in form was found throughout the entire latitudinal range. In terms of body proportions, no latitudinal gradients were evident, but a few local "morphotypes" could be distinguished. The distinctive egg mass morphology, and size and form features, including a hectocotylus $20-40 \%$ longer than the opposing ventral arm and the presence of suckers on the buccal membrane, indicated that Lolliguncula from northern and southern hemispheres might comprise two different taxa.
\end{abstract}

Key words: cephalopods, morphology, Loliginidae, Brazil.

\section{INTRODUCTION}

Lolliguncula Steenstrup, 1881 is one of the ten genera included in the Family Loliginidae (Vecchione et al. 2005), which comprises the most abundant squid forms found in coastal areas and continental shelves worldwide. Recent taxonomic reviews have established the validity of four to five Lolliguncula species, all of them small-sized squid occurring in warm coastal habitats such as shallow bays and estuaries (Vecchione et al. 1998, 2005). The geographic distribution of the genus is centered in the Panamá region, as most species are

Correspondence to: Tânia Zaleski

E-mail: taniazaleski@gmail.com limited to tropical and subtropical waters off both North and South American shores. L. panamensis, $L$. argus and $L$. diomedeae occur in the Pacific Ocean, whereas L. brevis occurs in the Atlantic side of the Americas and the Caribbean.

Originally included in the genus Loligo, Lolliguncula brevis was firstly described by Blainville in 1823 from specimens collected off South America. Solely based on male hectocotylus morphology as a diagnostic feature, this description was reviewed and complemented from the 1910's onwards as other morphological characters exhibited by North Atlantic specimens were compiled (Berry 1911, 1913, Voss 1956, Abbott 1974, Roper 1978, Roper 
et al. 1984). The species was then considered a single taxum with a wide latitudinal distribution in the Western Atlantic, occurring from $40^{\circ} \mathrm{N}$ (South Carolina) to $27^{\circ} \mathrm{S}$ (Santa Catarina) including the Gulf of Mexico and the Caribbean (Roper et al. 1984).

Records of the species in Brazilian waters only reappeared in the late 70's review of Brazilian cephalopod fauna by F.J. Palacio (unpublished data), and subsequent reports of scientific surveys off the Brazilian coast (M. Juanicó, unpublished data; Haimovici and Andriguetto-Filho 1986). Those records were compiled in more comprehensive reviews of cephalopod Brazilian fauna (Rios 1985, Haimovici et al. 1994, Perez and Haimovici 1991, Haimovici and Perez 1991), which extended the species distribution range in southern Atlantic as far south as Santa Catarina state $\left(28^{\circ} \mathrm{S}\right)$.

Morphologic and morphometric variability of Lolliguncula brevis was preliminarily analyzed by M. Juanicó (unpublished data), who noticed possible geographic patterns along the Brazilian coast. Later, a detailed study conducted by Simone (1997) evidenced differences between Brazilian and North American forms, suggesting that more than one species could have been included under the same name, and that a general review of this taxum was required. The present work explores both $\mathrm{M}$. Juanicó's (unpublished data) and Simone's (1997) hypotheses providing a detailed morphometric analysis of $L$. brevis collected along a significant part of its latitudinal range in the southern hemisphere, off the Brazilian coast $\left(8^{\circ} \mathrm{S}-27^{\circ} \mathrm{S}\right)$, complemented with a well development morphological description.

\section{MATERIALS AND METHODS}

This study was based on a total of 196 specimens of Lolliguncula brevis collected in Brazilian waters, including 112 females and 84 males (Table I). These specimens were obtained from 11 localities along the Brazilian coast, from Pernambuco state $\left(8^{\circ} \mathrm{S}\right)$ to Santa Catarina state $\left(27^{\circ} \mathrm{S}\right)$ (Figure 1$)$ The specimens of Rio de Janeiro state were part of the mollusca collection of Museu Nacional da Universidade Federal do Rio de Janeiro (MNRJ) (Lots 5,635; 5,634; 5,638 and 5,636). The remainders were collected in situ mostly by trawling in coastal areas. Egg masses were obtained from shrimp trawls over shallow sandy/muddy bottoms in Balneário Camboriú bay (Santa Catarina state; $\mathrm{n}=17$ egg masses) and Guaratuba bay (Paraná state; $n=4$ egg masses). All material was fixed in formalin $4 \%$ and preserved in ethanol $70 \%$.

TABLE I

Positions, latitude-longitude points (Lat-Long) and number of females and males of Lolliguncula brevis collected per sample for morphological and morphometric analysis. The numbers of locations sampled correspond to the points shown in Figure 1.

\begin{tabular}{cccccc}
\hline & Sampled locality & Lat-Long & + & $\hat{0}$ & Mantle lenght range (mm) \\
\hline 1 & Baía Sul & $27^{\circ} 35^{\prime} \mathrm{S}-48^{\circ} 32^{\prime} \mathrm{W}$ & - & 5 & $29.8-49.0$ \\
\hline 2 & Penha & $26^{\circ} 46^{\prime} \mathrm{S}-48^{\circ} 38^{\prime} \mathrm{W}$ & 10 & 10 & $25.0-47.6$ \\
\hline 3 & Itapoá & $26^{\circ} 07^{\prime} \mathrm{S}-48^{\circ} 36^{\prime} \mathrm{W}$ & 15 & 5 & $14.5-52.0$ \\
\hline 4 & Guaratuba & $25^{\circ} 51^{\prime} \mathrm{S}-48^{\circ} 39^{\prime} \mathrm{W}$ & 13 & 10 & $29.9-69.5$ \\
\hline 5 & Pontal do Sul & $25^{\circ} 35^{\prime} \mathrm{S}-48^{\circ} 21^{\prime} \mathrm{W}$ & 18 & 20 & $24.5-63.3$ \\
\hline 6 & Cananéia & $25^{\circ} 00^{\prime} \mathrm{S}-47^{\circ} 55^{\prime} \mathrm{W}$ & 10 & 10 & $25.8-43.4$ \\
\hline 7 & Ubatuba & $23^{\circ} 26^{\prime} \mathrm{S}-45^{\circ} 04^{\prime} \mathrm{W}$ & 10 & 10 & $24.0-46.4$ \\
\hline 8 & Ilha do Governador & $22^{\circ} 48^{\prime} \mathrm{S}-43^{\circ} 11^{\prime} \mathrm{W}$ & 8 & - & $26.0-47.0$ \\
\hline 9 & Rio das Ostras & $22^{\circ} 31^{\prime} \mathrm{S}-41^{\circ} 56^{\prime} \mathrm{W}$ & 13 & 4 & $30.0-62.5$ \\
\hline 10 & Baía de Camamu & $13^{\circ} 55^{\prime} \mathrm{S}-39^{\circ} 04^{\prime} \mathrm{W}$ & 10 & 10 & $30.0-55.7$ \\
\hline 11 & Recife & $13^{\circ} 55^{\prime} \mathrm{S}-39^{\circ} 04^{\prime} \mathrm{W}$ & 5 & - & $21.0-41.0$ \\
\hline Total & & 112 & 84 & $14.5-69.5$ \\
\hline
\end{tabular}


Specimens were examined in detail for the general external morphology, and measurements were based in Roper and Voss (1983): mantle length (ML), mantle width (MW), length of siphon (SL), fin length (FL), fin width (FW), head length (HL), head width (HW), eye diameter (ED), intra-orbital distance (IOD), length of the right arms (ALI, ALII, ALIII, ALIV), width of the right arms (AWI, AWII, AWIII, AWIV), right tentacle length (TL), tentacular club length (TCL), sucker diameter (SD), number of suckers in arms (SNI, SNII, SNIII, SNIV), total number of suckers in the hectocotylus (SNHe), number of suckers in the tentacle (SNT), number of right gill lamellae (GLN). In males, the length and width of the hectocotylus were taken ( $\mathrm{HeL}$ and HeW respectively) as well as length and width of the opposing arm. The gladius was dissected from the gladius sac and measured for the total length (GTL), vane width (GVW), rachis length (GRL) and rachis width (GRW). Individual eggs and egg capsules were measured for the total length, the number of eggs per capsule and the number of capsules per egg mass was also recorded.

The radula of additional ten females and eight males caught off Santa Catarina state coast was extracted from the buccal mass and prepared for observation under JEOL JSM 6360LZ, a Scanning Electron Microscope.
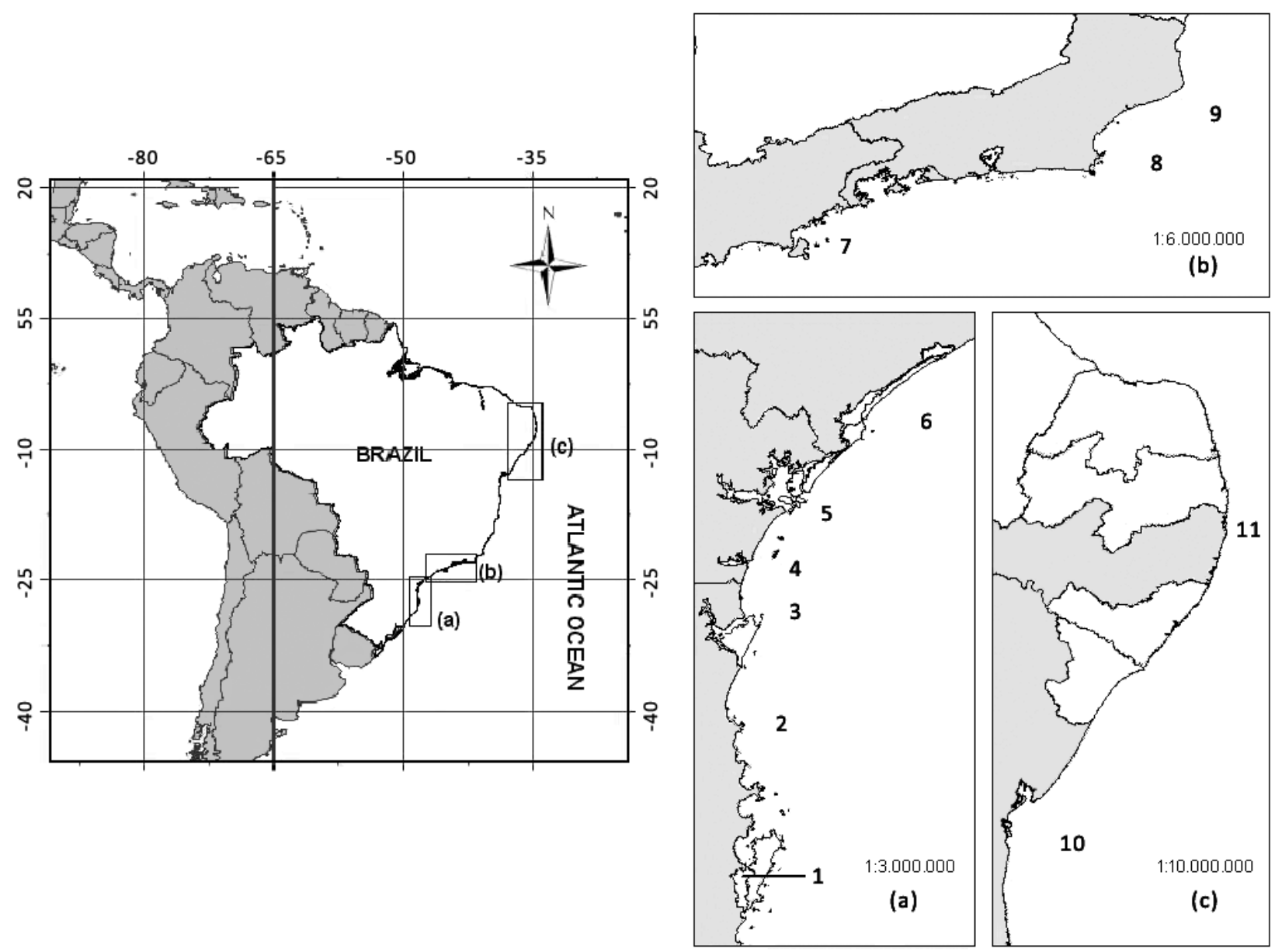

Figure 1 - Study area and positions where Lolliguncula brevis were sampled for morphological and morphometric analysis. Three sectors of the Brazilian coast are presented in detail depicting specific localities and coastline features. Number of females and males collected per sample, locality and latitude-longitude points are indicated Table I. 
All measurements were log-transformed and their variability tested for the effect of sex and collection locality using an Analysis of Covariance (ANCOVA), where each measurement was the dependent variable, sex or locality were effect factors, and mantle length (ML) the covariate. Each ANCOVA was preceded by a test for homogeneity of slopes (Zar 1982) where the interactions between the effect factors and the covariate were tested. When such interactions were significant the ANCOVA was not applied.

A Principal Component Analysis (PCA) was applied as a variable reduction technique, and aimed at assessing morphological similarities among the examined specimens and the characterization of eventual morphotypes (Hair-Júnior et al. 1995, Monteiro and Reis 1999). PCA was applied for males and females separately and included the following measurements ML, MW, FL, FW, HL, HW, IOD, ED, AL I, AL II, AL III, AL IV, AW I, AW II, AW III, AW IV. These variables were chosen because they were available in most examined specimens, thus allowing the analysis to include the largest sample size. In males, hecocotylus length (HeL) and width (HeW) were also included. All variables were standardized to preserve allometric relationships, variance and equalize errors existent in wide size variations (Bookstein et al. 1985, Voight 1991), using the formula:

$$
S V_{i}=\frac{V_{i}-V_{m}}{\sigma}
$$

Where $S V_{i}$ is the i-eth standardized variable, $V_{i}$ is the $i$-eth original variable, $V_{m}$ is the variable mean and $\sigma$ the variable standard deviation.

\section{RESULTS}

All examined specimens were included in the genus Lolliguncula based on rounded fins and a spermatophore-pad near the left gill (Brakoniecki 1980). Mantle was short, cylindrical and slightly rounded at the posterior end (Figure 2A, B and C). The dorsal margin was wide with a distinct dorsal lappet marking the anterior end of the gladius. Ventrally, the mantle margin was slightly concave at the basis of the siphon. This concavity was delimited by a pair of lappets that marked externally the position of mantle locking apparatus. Mantle width at its midpoint varied between $26 \%$ and $44 \%$ of the ML. Fins were round-shaped (Figure 2A, B), wider at their midportion ( $78 \%$ of $\mathrm{FL}$ ), their length reaching $35-45 \%$ of the length of the mantle.

Head was as wide as the mantle or slightly narrower than it (Figure 2A, B). Head length reached, on average $1 / 4$ of ML. Eyes were mediumsized, reaching approximately $68 \%$ of head length. Siphon was compact, extending anteriorly to the approximate midpoint of the eyes (Figure 2C). The funnel locking cartilages had a straight, groove and the mantle-locking cartilages were straight ridges.

Arms were medium-sized reaching 25$75 \%$ of ML. Most frequent arm formulae was $\mathrm{IV} \cong \mathrm{III}>\mathrm{II}>\mathrm{I}$. All arms presented poorly developed sucker protecting membranes that extended along the margin of part of its length. Arm III, however, was bordered by a well-developed swimming membrane extending along its entire length. A total of 31-103 suckers, disposed in two rows, were counted on the oral surface of each arm, on average. Sucker chitinous rings had 7-8 squared similar teeth on half of the ring perimeter, being the other half smooth. The seven-lobbed buccal membrane contained a variable number of the small suckers on the oral surface.

Males' left ventral arm was modified into a hectocotylus, reaching $60 \%$ ofmantle, being noticeably longer than the opposing ventral arm (Figure 2B; 5B). Suckers at approximately $1 / 3$ of the distal dorsal row were gradually reduced (the 1 to 3 proximal modified suckers being greatly reduced in diameter) toward the arm tip. These modified suckers lie on the tip of long triangular pedicels, which diminish in size distally (Figure 2E). Four males caught at "Baía Sul" (the 

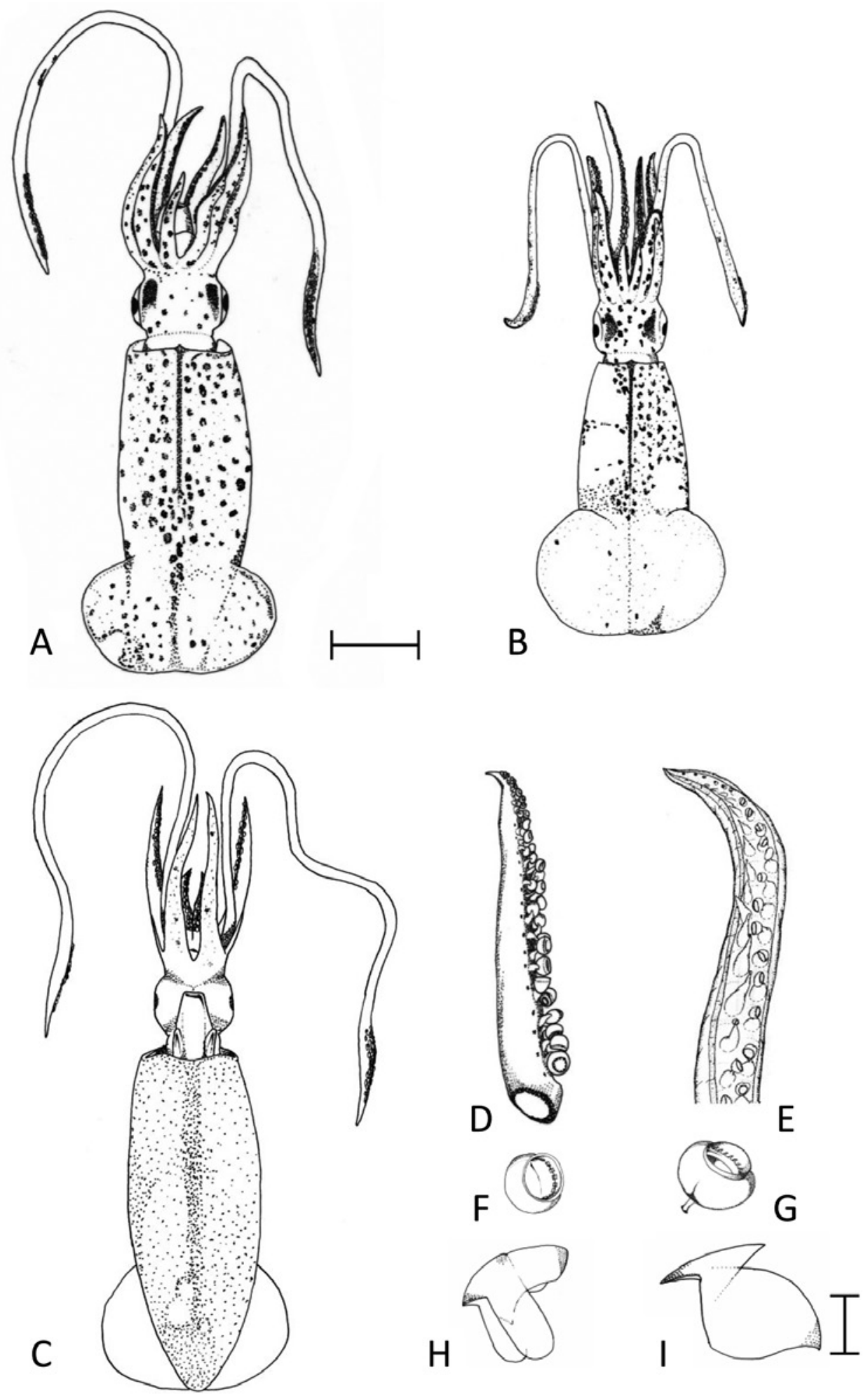

Figure 2 - Lolliguncula brevis of Brazilian coast. A- Female, dorsal view. B- Male, dorsal view. C- Female, ventral view (A, B, C: horizontal bar 10 mm). D- Second arm (mean length $16 \mathrm{~mm}$ ). E- Hectocotylus (mean length $22 \mathrm{~mm}$ ). F- Arm sucker (diameter between 0.1 and $1.2 \mathrm{~mm}$ ). G- Sucker of the internal line of manus of tentacles (diameter between 0.3 and $2.5 \mathrm{~mm}$ ); H- Lower beak; I- Upper beak (H, I: vertical bar $0.06 \mathrm{~mm}$ ). 
southernmost locality sampled) had a distinctively bare hectocotylized portion of the left ventral arm, without suckers or pedicels.

Tentacles were long and laterally compressed. Clubs were bordered by a short swimming membrane. Suckers were larger at the manus and smaller at the dactylus decreasing in diameter towards the distal end of the club. These suckers were arranged in approximately 27 transversal and four longitudinal rows. Chitinous rings of club suckers had pointy teeth (Figure 2G).

Externally, preserved specimens were normally white to pale yellow. Dark chromatophores were scattered over the entire mantle surface, being more concentrated on the dorsal surface and particularly along the external gladius outline. Some specimens presented a darker band on the ventral longitudinal midline (Figure 2C). Chromatophores also covered both dorsal and ventral surfaces of the head. The siphon was only pigmented on the ventral surface. Arms and tentacles were pigmented at their aboral surfaces.

Beaks were light in color and moderately short (Figure 2H and I). Radula was composed by chitinous

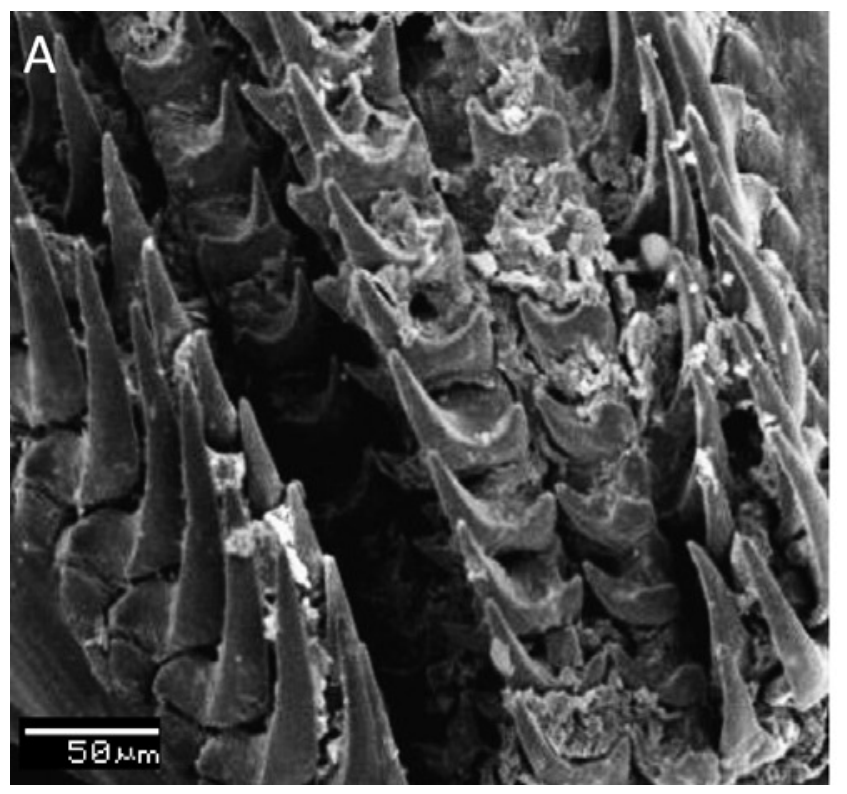

teeth regularly arranged in seven longitudinal rows. Rachidian (central) teeth were tricuspid, the mesocone being longer and pointier than the lateral cuspids. The first lateral teeth were longer than the rachidian teeth and bear two cuspids, the central cuspid being was than the marginal one towards. The second lateral teeth were long and formed by a single triangular cuspid. The third lateral teeth were slightly long with round borders, rectangular marginal plates were present (Figure 3).

The gladius was translucid, moderately short with a wide vane (vane width reached approximately $20 \%$ of gladius length). Rachis was narrow (mean width $1.6 \mathrm{~mm}$ ) with a pointed anterior end (Figure 4). The anterior margin of the vane was straight and continuous to the rachis margin. Posteriorly the vane was round-shaped. Its margins were slightly curved and not thickened laterally. Internally, paired gills bear 70 lamellae each one.

In mature females, the genitalia (ovary, oviduct, nidamental glands and oviducal gland) occupied approximately $2 / 3$ of the mantle visceral space. The oviduct was single and ran parallel

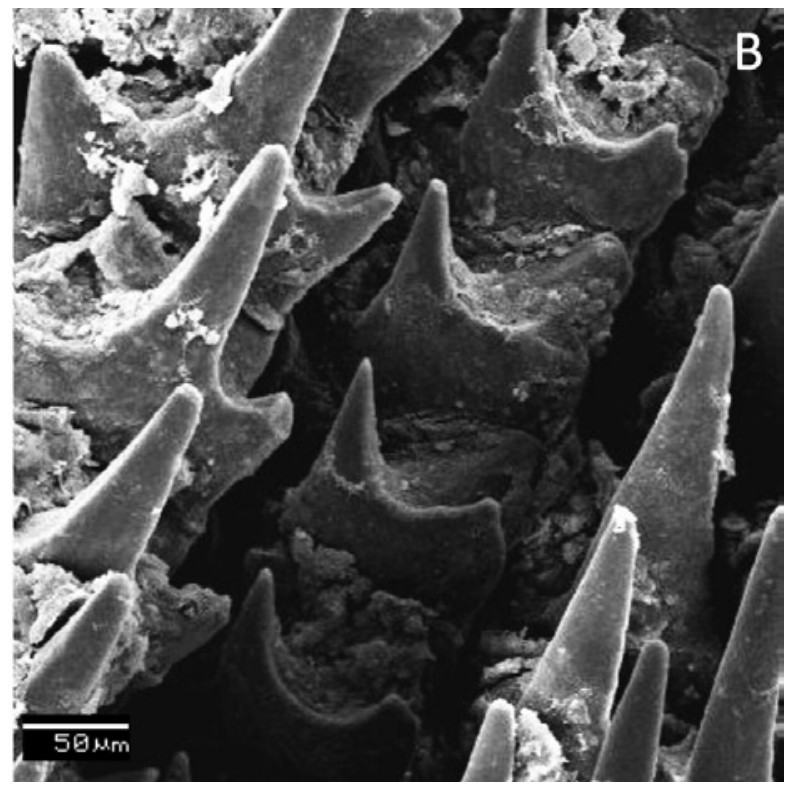

Figure 3 - Radula of Lolliguncula brevis of the Brazilian coast, viewed under scanning electron microscopy. A. Rachidian (central) and lateral teeth. B. Detail of the previous image. 


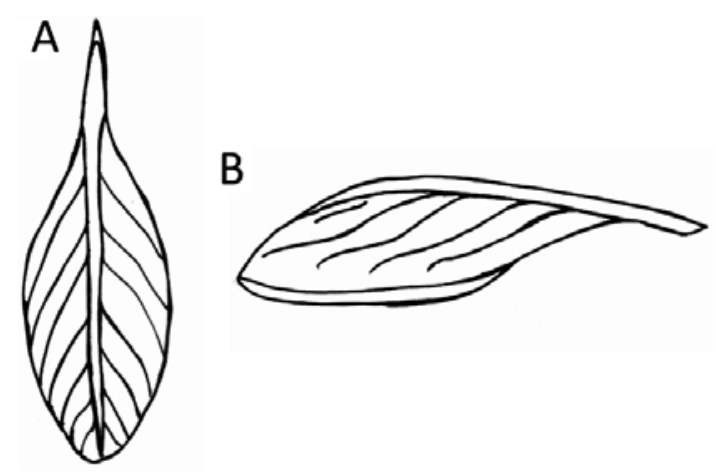

Figure 4 - Dorsal and lateral aspects of gladius of Lolliguncula brevis.

to the digestive caecum. Developed nidamental glands were lamellar and bulky, occupying most of the visceral cavity. The oviducal gland was also greatly developed in mature females and located on the left side of the mantle. Mated females had spermatangia inserted in the muscles of the inner mantle, at the basis of the left gill in the vicinity of the oviduct aperture (Figure 5C, D). In mature males the testis was a white and conical mass located at the posterior end of the visceral cavity. The terminal organ or penis was wide and with a thin and translucid wall. Spermatophores were long and thin. The cement body was long and slender, occupying approximately $1 / 3$ of the spermatophores total length.

Egg masses from both "Guaratuba" and "Balneário Camboriú" were similar in form. These were clusters/clutches of 18-73 short and globuleshaped gelatinous capsules, each one with a peduncule whose length never exceeded half of the capsule total length (Figure 5E, F). These capsules were fused by their peduncles into a common stalk by which the cluster was attached to the substrate. When immersed in water egg clusters formed a sphere with 6-7 $\mathrm{cm}$ radius.

Egg capsules were 9.4-28.5 mm long. Each capsule was formed by a string of eggs enclosed in two gelatinous layers, an inner layer that held the eggs together in a spiral thread, and an outer one that enveloped this thread and delineated the capsule and also the peduncule. Each capsule enclosed 1-38 eggs/embryos (mean $18 \pm 0.4$ SEM, $\mathrm{n}=391)$. Developmental stages observed were 7-27 (according to Arnold 1971 and Hunter and Simon 1975). The chorion was ovate (with 1.3-1.7 mm length in the longest axis) in the youngest stage observed. The length increase to 2.5-3.5 mm during organogenesis (stages 18, 19, 20, 21) (Figure 6).

\section{MORPHOMETRIC ANALYSIS}

Males and females differed in all but one body measurement (SNT, Table II). This justified the following analysis (ANCOVA) to be conducted for each sex separately. In both sexes, almost all body measurements varied significantly among localities (Table III).

The first and second rotated axes (Factors I and II) generated by the PCA applied to female body measurements accounted for $54 \%$ and $15 \%$ of total variance, respectively. Higher scores of the first axis were attributed to females with a longer mantle length, longer arms and longer and wider fins. In the second axis, high scores were determined by more robust (wider) arms (Table IV). When examined females were plotted according to the scores determined by factors I and II. No distinct groups could be spatially observed (Figure 7A).

In males, the first and second PCA rotated axis (factors) accounted for $43 \%$ and $12 \%$ of the total variance, respectively. Specimens scored by factor I were positively influenced by the length of their head, arms and mantle, whereas factor II scores were mostly driven by the positive effect of hectocotylus length and negative effect of arm IV length, fin length and mantle length (Table IV). The spatial representation of examined males, as scored by factors I and II, allowed the distinction of a few regional groups or "morphotypes" (Figure 7B). The most distinctive ones originated from (a) "Cananéia", generally smaller, with narrow head, short to medium arms, short fins, and long hectocotylus; (b) "Camamu”, slightly larger and with arms longer than the ones in the group from 

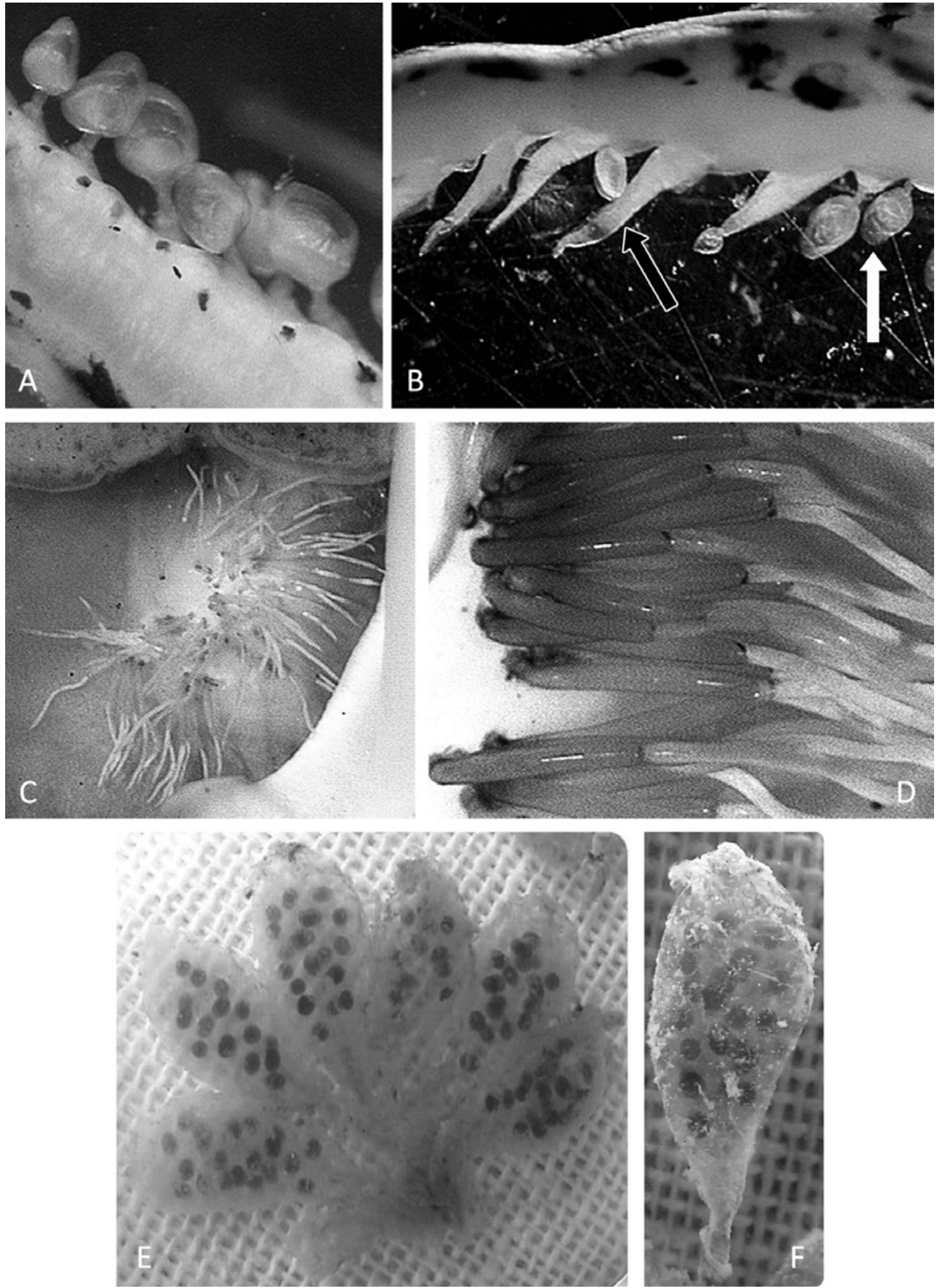

Figure 5 - Anatomical features of Lolliguncula brevis of Brazil. A- Suckers on second arm. B- Hectocotylus of male (white arrow: normal sucker and black arrow: modified sucker). C-and D- Spermatangias inserted in the inner mantle wall of a female. E- Egg mass, i.e., egg capsules fused by their peduncles into a common stalk. F- Detail of egg an capsule. 


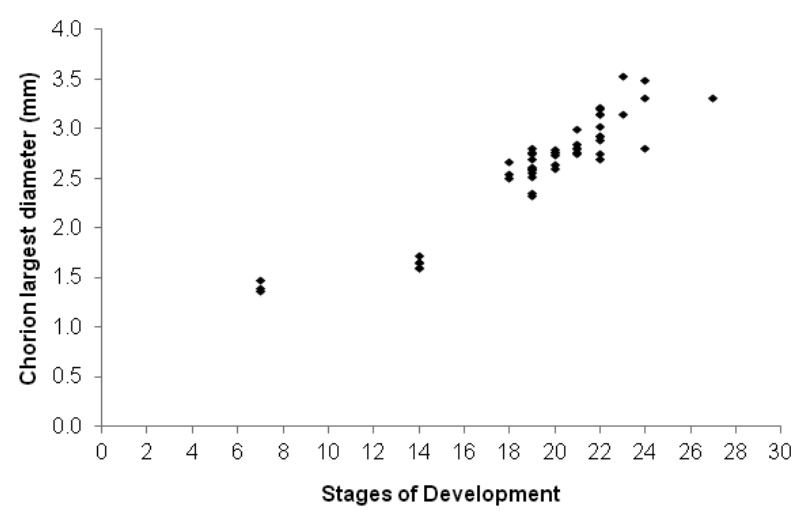

Figure 6 - Increase the size of the chorion of the L. brevis in relation to the stages of egg development.

Cananéia; and (c) "Baía Sul", with wide head, long arms and short hectocotylus. Squids from localities separated by long distances such as "Camamu" and "Guaratuba" were relatively similar. On the other hand; squids from relatively close localities such as "Baía Sul", "Penha" and "Cananéia" appeared as distinct forms in the bidimensional space.

\section{DISCUSSION}

Lollingunculla specimens collected off Brazilian coast between $8^{\circ} \mathrm{S}-27^{\circ} \mathrm{S}$ were morphologically similar and probably comprise a single taxum. Males morphometric analysis, however, revealed geographic dissimilarities in body proportions and the differentiation of local "morphotypes" within the sampled geographic range. Such dissimilarities could not $a$ priori be associated with the distance between localities or latitudinal gradients; squid groups of neighboring localities could be more dissimilar than groups nearly $2,000 \mathrm{~km}$ apart. That, in turn, suggests that the population structure of $L$. brevis along its wide latitudinal range can be complex, and exclusive phenotypes can be maintained in relatively small and enclosed areas, such as bays and estuaries. Two main hypotheses can be drawn as plausible causes of such variability in form.

First, local forms could be the outcome of character plasticity as influenced by local environmental (temperature, salinity, food availability) regimes. Notwithstanding being influenced by the overall latitudinal climate gradient, most localities are associated to complex estuarine systems (i.e. "Camamu", "Cananéia", "Guaratuba", "Pontal do Sul", "Rio das Ostras"), each one of them with very particular environmental conditions (Castro-Filho et al. 1987, Pires-Vanin and Matsuura 1993, Panitz 1994). Phenotypic plasticity is well documented in cephalopods, including some extreme cases such as Loligo forbesii, in which forms inhabiting waters of the vicinity of the Azores Archipelago differed radically in size and form from more typical forms inhabiting the European shelf(Brierley et al. 1993).

A second possibility could be the intraspecific phenotypic variation as determined by a limited gene flow among local groups, leading to some degree of genetic isolation. In cephalopods, as in most marine invertebrate and fish groups, such limitation could be associated to (a) the dispersion capacity of planktonic initial life stages, and (b) to the locomotion power of nektonic adults. In the first case, the smaller the hatchlings, the longer the duration of the planktonic life and higher is the dispersion capacity (Boletzky 1987, Vecchione 1987). Lolliguncula are generally large-egged, with a relatively short nektobenthic planktonic life in comparison with Loligo species, for example (Hall 1970, Vecchione 1982, Boyle and Rodhouse 2005). That feature per se suggests limited paralarval dispersion.

Additionally, as adults, L. brevis may not be able to perform long displacements owing to the elevated locomotion demands characteristic of small-sized squid. In fact, as squid body increases, velocity is also increased while transportation costs decrease (O’Dor 1988). Loligo opalescens, which reach sizes as large as $13 \mathrm{~cm}$ ML, have its maximum migratory amplitude estimated at around $600 \mathrm{~km}$. Although this species is distributed along nearly $3,500 \mathrm{~km}$ off the west coast of North America, three morphologically distinct populations are found in three adjacent 
TABLE II

Summary of morphometric analysis of Lolliguncula brevis collected off Brazilian coast.

\begin{tabular}{|c|c|c|c|c|}
\hline \multirow{2}{*}{ VARIABLES } & \multicolumn{2}{|c|}{$\mathrm{MEAN} \pm \mathrm{SEM}$} & \multirow{2}{*}{ THS } & \multirow{2}{*}{ ANCOVA } \\
\hline & $\mathrm{F}$ & M & & \\
\hline MW & $15.3 \pm 0.33$ & $11.0 \pm 0.27$ & $0.06^{*}$ & $0.00^{*}$ \\
\hline FL & $17.8 \pm 0.46$ & $11.6 \pm 0.30$ & $0.26^{*}$ & $0.00^{*}$ \\
\hline FW & $26.0 \pm 0.68$ & $18.3 \pm 0.44$ & $0.50 *$ & $0.00 *$ \\
\hline HL & $10.8 \pm 0.18$ & $9.0 \pm 0.13$ & $0.19^{*}$ & $0.00 *$ \\
\hline HW & $12.5 \pm 0.20$ & $10.6 \pm 0.16$ & $0.59^{*}$ & $0.00 *$ \\
\hline IOD & $9.4 \pm 0.18$ & $7.7 \pm 0.15$ & $0.29^{*}$ & $0.00 *$ \\
\hline ED & $7.3 \pm 0.12$ & $6.1 \pm 0.09$ & 0.01 & - \\
\hline ALI & $12.0 \pm 0.32$ & $9.3 \pm 0.25$ & $0.61^{*}$ & $0.00 *$ \\
\hline AWI & $1.4 \pm 0.05$ & $0.9 \pm 0.03$ & 0.01 & - \\
\hline ALII & $17.0 \pm 0.38$ & $14.1 \pm 0.30$ & $0.15^{*}$ & $0.00 *$ \\
\hline AWII & $1.9 \pm 0.06$ & $1.5 \pm 0.04$ & 0.02 & - \\
\hline ALIII & $21.3 \pm 0.43$ & $18.8 \pm 0.36$ & $0.13 *$ & $0.00^{*}$ \\
\hline AWIII & $2.3 \pm 0.06$ & $1.8 \pm 0.04$ & 0.01 & - \\
\hline ALIV & $23.0 \pm 0.50$ & $18.9 \pm 0.37$ & $0.20 *$ & $0.00^{*}$ \\
\hline AWIV & $3.4 \pm 0.11$ & $2.7 \pm 0.10$ & 0.04 & - \\
\hline SNAI & $40 \pm 0.63$ & $34 \pm 0.50$ & $0.10^{*}$ & $0.00^{*}$ \\
\hline SNAII & $51 \pm 0.82$ & $45 \pm 0.67$ & $0.60^{*}$ & $0.00 *$ \\
\hline SNAIII & $57 \pm 0.77$ & $53 \pm 0.59$ & $0.66^{*}$ & $0.00^{*}$ \\
\hline SNAIV & $67 \pm 1,00$ & $61 \pm 0.92$ & $0.47^{*}$ & $0.00^{*}$ \\
\hline SNT & $110 \pm 2.27$ & $110 \pm 2.34$ & $0.62 *$ & 0.13 \\
\hline GLN & $71 \pm 0.87$ & $67 \pm 0.94$ & $0.31 *$ & $0.01^{*}$ \\
\hline SL & $10.9 \pm 0.18$ & $8.6 \pm 0.16$ & $0.46^{*}$ & $0.00^{*}$ \\
\hline GTL & $42.3 \pm 0.88$ & $30.7 \pm 0.43$ & $0.09 *$ & $0.00^{*}$ \\
\hline GVW & $10 \pm 0.28$ & $6.2 \pm 0.16$ & $0.84 *$ & $0.00^{*}$ \\
\hline GRL & $13.7 \pm 0.37$ & $11.3 \pm 0.24$ & $0.08^{*}$ & $0.00^{*}$ \\
\hline GRW & $1.9 \pm 0.07$ & $1.3 \pm 0.05$ & $0.28 *$ & $0.00 *$ \\
\hline
\end{tabular}

Females and males mean body measurements $( \pm$ SEM) and the results of statistical tests are indicated. Each ANCOVA (Analysis of Covariance); was preceded by a test for homogeneity of slopes (THS). The asterisk indicates significant differences between sexes $(\alpha=0.05)$.

zones, suggesting that the migration amplitudes could be much smaller (Kashiwada and Recksiek 1978). L. brevis is, on average, much smaller than L. opalescens, thus their migratory capacity is expected to be even more restricted. Such limited migratory amplitude, combined with the effect of local environmental conditions, could result in slightly distinct forms of Lolliguncula brevis along Brazilian large and diverse coastline.
In the North Atlantic and Caribbean waters, the validity of a single taxum, L. brevis, has been generally supported (Jereb et al. 2010). Nevertheless, the present analysis, including a large number of specimens collected along a significant portion of the species distribution in the South Atlantic, reinforces, in accordance with a previous study (Simone 1997) that northern and southern hemisphere forms cannot be classified under the same name. 
TABLE III

Summary of the morphometric analysis of Lolliguncula brevis collected off Brazil.

\begin{tabular}{ccccc}
\hline & \multicolumn{2}{c}{ FEMALES } & \multicolumn{2}{c}{ MALES } \\
\hline & THS & ANCOVA & THS & ANCOVA \\
\hline MW & $0.21^{*}$ & $0.00^{*}$ & $0.85^{*}$ & $0.00^{*}$ \\
\hline FL & 0.04 & - & $0.75^{*}$ & $0.01^{*}$ \\
\hline FW & 0.01 & - & $0.89^{*}$ & $0.00^{*}$ \\
\hline HL & 0.01 & - & $0.17^{*}$ & $0.00^{*}$ \\
\hline HW & $0.73^{*}$ & $0.00^{*}$ & 0.03 & - \\
\hline IOD & $0.61^{*}$ & $0.00^{*}$ & $0.40^{*}$ & $0.00^{*}$ \\
\hline ED & $0.14^{*}$ & $0.00^{*}$ & $0.07^{*}$ & $0.00^{*}$ \\
\hline ALI & $0.14^{*}$ & $0.03^{*}$ & $0.91^{*}$ & $0.00^{*}$ \\
\hline AWI & 0.02 & - & $0.46^{*}$ & 0.36 \\
\hline ALII & $0.06^{*}$ & $0.00^{*}$ & $0.33^{*}$ & $0.00^{*}$ \\
\hline AWII & $0.81^{*}$ & 0.60 & $0.06^{*}$ & $0.04^{*}$ \\
\hline ALIII & 0.00 & - & $0.31^{*}$ & $0.00^{*}$ \\
\hline AWIII & $0.13^{*}$ & $0.00^{*}$ & $0.17^{*}$ & $0.00^{*}$ \\
\hline ALIV & $0.86^{*}$ & $0.00^{*}$ & 0.00 & - \\
\hline AWIV & $0.40^{*}$ & $0.00^{*}$ & $0.65^{*}$ & $0.00^{*}$ \\
\hline HEL & & & $0.37^{*}$ & $0.00^{*}$ \\
\hline HEW & & & $0.72^{*}$ & $0.00^{*}$ \\
\hline
\end{tabular}

Body measurements of female and males were tested for differences among 11 localities. Each ANCOVA (Analysis of Covariance) was preceded by a test for homogeneity of slopes (THS). The asterisk indicates significant differences among localities $(\alpha=0.05)$.

Southern males and females reached body sizes as large as 49.0 and $69.5 \mathrm{~mm}$ ML, respectively, being consistently smaller than Lolliguncula brevis recorded off Central and North America (Table V). In contrast with northern forms (Roper et al. 1984), Lolliguncula brevis collected off Brazil are also less robust, with a slender cylindrical mantle (a feature also reported by Simone 1997) and exhibit shorter and narrower fins. Additionally, the morphology of egg capsules and egg masses collected off southern Brazil greatly differs from the observed in the North American coast. Hall's (1970) description of Loliguncula brevis spawning in Tampa Bay, Gulf of Mexico, refers to long egg-capsules fixed individually to the substrate, enclosing 56-88 eggs, whereas the ones collected off southern Brazil were five times shorter, united by a common stalk and fixed as a bunch, enclosing 1-38 eggs (Table V).

Southern L. brevis males were also distinguished from northern forms by exhibiting a hectocotylized arm bearing 17 modified suckers and $20-40 \%$ longer than the opposing ventral arm. Roper et al. (1984) reported these arms as subequal in north Atlantic Lolliguncula. Lastly, unlike the specimens collected off Brazil, northern Loligunculla do not seem to bear suckers on the buccal membrane (Roper 1978), although some uncertainty exists about this character (Roper 1978).

Morphological differences between northern and southern forms, as evidenced in this study, 

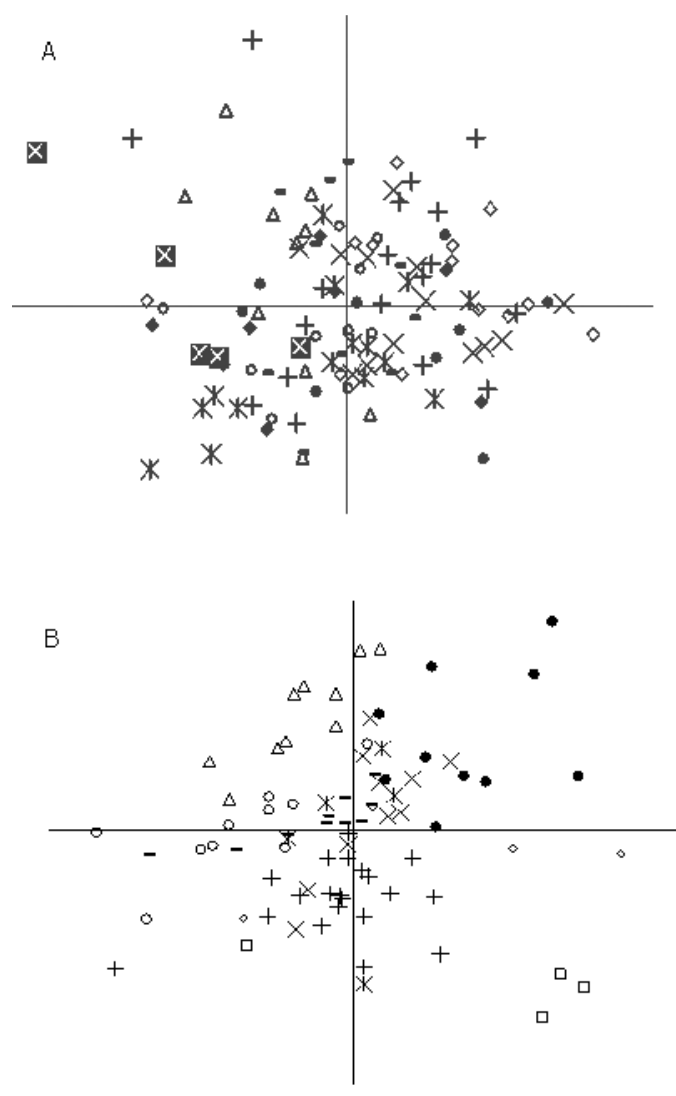

Figure 7 - Spatial representation of specimens of Lolliguncula brevis from Brazil as scored by the first two factors obtained from the Principal Component Analysis. Factor I, horizontal axis. Factor II, vertical axis. (A) Females; (B) Males; $\times$ Recife; $\bullet$ Bahia; $\diamond$ Rio de Janeiro; - Ilha do Governador; - Ubatuba; $\triangle$ Cananéia; + Pontal do Sul; $\times$ Guaratuba; * Itapoá; ○ Penha; $\square$ Baía Sul.

seems to justify their separation in different species of the genus Lolliguncula (Lolliguncula), one occurring from North Carolina to Caribbean Sea, and the other from Pernambuco to Santa Catarina. However, a definitive conclusion should be reached after a genetic evaluation and a detailed comparative morphological samples study throughout the geographic range. If confirmed, a question will still remain: which of the geographic forms should be rightfully considered as Lolliguncula brevis. The type locality is believed to be the coast of Rio the Janeiro (referred type locality near Rio de Janeiro; Voss 1956), although this information is not completely clear in Blainville's original description and could
TABLE IV

Principal Component Analysis (PCA) applied to morphometric data of Lolliguncula brevis collected off Brazil. Weights of the variables in the first two factors rotated by the PCA (F1 and F2) are indicated for females and males. The eigenvalues and the variance explained by each factor are indicated in the last two rows.

\begin{tabular}{|c|c|c|c|c|}
\hline & \multicolumn{2}{|c|}{ Females } & \multicolumn{2}{|c|}{ Males } \\
\hline & $\mathrm{F} 1$ & $\mathrm{~F} 2$ & $\mathrm{~F} 1$ & $\mathrm{~F} 2$ \\
\hline $\mathrm{ML}$ & 0.31 & 0.07 & 0.27 & -0.35 \\
\hline MW & 0.24 & 0.04 & 0.20 & 0.23 \\
\hline $\mathrm{FL}$ & 0.31 & 0.07 & 0.25 & -0.32 \\
\hline FW & 0.29 & 0.11 & 0.20 & 0.23 \\
\hline HW & 0.29 & 0.06 & 0.20 & 0.23 \\
\hline HL & 0.26 & 0.09 & 0.30 & -0.08 \\
\hline IOD & 0.29 & 0.09 & 0.21 & -0.29 \\
\hline ED & 0.25 & 0.06 & 0.16 & 0.26 \\
\hline ALI & 0.27 & 0.02 & 0.27 & 0.07 \\
\hline AWI & -0.13 & 0.46 & 0.16 & 0.09 \\
\hline ALII & 0.28 & 0.03 & 0.27 & 0.23 \\
\hline AWII & -0.10 & 0.51 & 0.19 & 0.10 \\
\hline ALIII & 0.29 & 0.08 & 0.28 & 0.23 \\
\hline AWIII & -0.12 & 0.50 & 0.17 & 0.01 \\
\hline ALIV & 0.30 & 0.06 & 0.29 & 0.16 \\
\hline AWIV & -0.11 & 0.47 & 0.23 & -0.31 \\
\hline HeL & & & 0.23 & 0.46 \\
\hline $\mathrm{HeW}$ & & & 0.24 & -0.16 \\
\hline Eigenvalue & 3.84 & 2.72 & 4.12 & 3.81 \\
\hline $\begin{array}{c}\text { Variance } \\
\text { explained \% }\end{array}$ & 54.4 & 15.4 & 43.0 & 12.3 \\
\hline
\end{tabular}

be as far north as the Caribbean. In any case, a major redescription of both forms will be necessary, and possibly a revalidation of some of $L$. brevis at least four available synonyms (Vecchione et al. 1998).

\section{ACKNOWLEDGMENTS}

We are indebted to Arnaldo C. S. Coelho, and Norma C. S. for the access to Rio de Janeiro museum collections and samples. Also Igor Soares for most squid drawings. We also thank Carlos Borzone, José Milton Andriguetto-Filho and Rodrigo Silvestre Martins for critically reviewing the original manuscript, and anonymous reviewers for the valuable suggestions. The senior author 
TABLE V

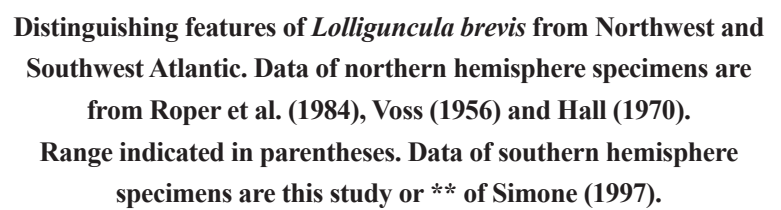

\begin{tabular}{|c|c|c|}
\hline & South & North \\
\hline ML max. (mm) & $\begin{array}{c}\text { o: } 73 * * \\
\text { o: } 49\end{array}$ & $\begin{array}{c}\text { of: } 120 \\
\text { J: }: 80\end{array}$ \\
\hline FL/ML (\%) & $40(20-37)$ & 55 \\
\hline FW/ML (\%) & $57-74$ & 84 \\
\hline HeL/ALIV & $1.2-1.4$ & 1.0 \\
\hline $\begin{array}{l}\text { Number of modified } \\
\text { suckers on the } \\
\text { hectocotylus }\end{array}$ & $17(0-22)^{*}$ & 24 \\
\hline Color & White to Yellow & Red-brownish \\
\hline $\begin{array}{l}\text { Number of eggs per } \\
\text { capsule }\end{array}$ & $18 \pm 0.4(1-38)$ & $69(56-88)$ \\
\hline $\begin{array}{l}\text { Egg capsule length } \\
(\mathrm{mm})\end{array}$ & $9-28$ & $100-130$ \\
\hline $\begin{array}{l}\text { Number of capsules } \\
\text { per egg mass }\end{array}$ & $18-73$ & Individually \\
\hline $\begin{array}{l}\text { Suckers on buccal } \\
\text { membrane }\end{array}$ & Present & $?$ \\
\hline
\end{tabular}

* Amplitude. 0- indicates the number of modified suckers in "Baía Sul" exemplars.

was supported by the Conselho Nacional de Desenvolvimento Científico e Tecnológico (CNPq), $\mathrm{MSc}$ Schollarship. J.A.A.P. is supported by a CNPq research grant (Process 309837/2010-3).

\section{RESUMO}

A variabilidade morfológica e morfométrica do pequeno loliginídeo costeiro Lolliguncula brevis foi avaliada ao longo da maior parte de sua amplitude latitudinal no hemisfério sul, ao longo da costa brasileira $\left(8^{\circ} \mathrm{S}\right.$ $27^{\circ} \mathrm{S}$ ). Uma homogeneidade na forma foi observada em toda sua área de ocorrência. Em termos de proporções corporais, não foram observados gradientes latitudinais evidentes, mas alguns "morfotipos" locais puderam ser distinguidos. O tamanho e as formas características, incluindo a presença de ventosas na membrana bucal, hectocótilo cerca de $20-40 \%$ maior do que o braço oposto ventral e a distinta morfologia da massa dos ovos sugerem que Lolliguncula ocorrentes no hemisférios norte e sul devam pertencer a táxons diferentes.

Palavras-chave: cefalópodes, morfologia, Loliginidae, Brasil.

\section{REFERENCES}

AввOтt RT. 1974. American Sea Shells, $2^{\text {nd }}$ ed., New York: van Nostrand Reinhold, $663 \mathrm{p}$.

ARNOLD JM. 1971. Cephalopods. In: Reverser G (Ed), Experimental embryology of marine and fresh water invertebrates. North Holland, Chicago: Illinois, p. 265-311.

BERRY SS. 1911. A note on the genus Lolliguncula. Proc Acad Nat Sci Phila 63(1): 100-105.

BERRY SS. 1913. Teuthological miscellany No. 1. A second note on the genus Lolliguncula. Zool Anz 42(13): 590-592.

BoletzKy S. 1987. Juvenile behavior. In: Boyle PB (Ed), Cephalopod life cycles vol 2. London: Academic Press, London, p. 45-60.

BoOKSTEIN FL, CHERnOFF B, ELDER R, Humphries J, SMITH G AND STRAUSS R. 1985. Morphometrics in Evolutionary Biology. Proc Acad Nat Sci Phila. Special Publication n. 15. Philadelphia, $277 \mathrm{p}$.

Boyle PR AND Rodhouse PG. 2005. Cephalopods: Ecology and fisheries. Blackwell Science, $452 \mathrm{p}$.

BRAKONIECKI TF. 1980. Lolliguncula tydeus, new species of squid (Cephalopoda: Myopsida) from the Pacific coast of Central America. Bull Mar Sci 30(2): 424-430.

BRIERLEY AS, THORPE JP, ClARKE MR AND MARTINS HR. 1993. A preliminary biochemical genetic investigation of the population structure of Loligo forbesi Steenstrup, 1856 from the UK and the Azores. In: Okutani T, O'Dor RK and Kubodera T (Eds), Recent advances in cephalopod fishery biology, Tokyo: Tokai University Press, p. 61-69.

Castro-Filho BM, Miranda LB AND MyaO SY. 1987. Condições hidrográficas na plataforma continental ao largo de Ubatuba: variações sazonais e em média escala. Bol Inst Ocean São Paulo 35(2): 135-151.

HAIMOVICI M AND ANDRIGUETTO-FILHO JM. 1986. Cefalópodes costeiros capturados na pesca de arrasto do litoral sul do Brasil. Arq Biol Tecnol 29(3): 473-495.

HAIMOVICI M AND PEREZ JAA. 1991. Abundância e distribuição de cefalópodes em cruzeiros de prospecção pesqueira demersal na plataforma externa e talude continental do Sul do Brasil. In: Castello JP and Haimovici M (Eds), Simpósio da FURG de Pesquisa Pesqueira: Atlântica 13(1): 189-200.

Haimovici M, Perez JAA AND SAntos RA. 1994. Class Cephalopoda Cuvier, 1798. In: Rios EC (Ed), Seashells of Brazil, $2^{\text {nd }}$ ed., Rio Grande: Editora da FURG, Rio Grande do Sul, p. 311-320.

HAIR-JÚNIOR JF, ANDERSON RS, TATHAM RL AND BLACK WC. 1995. Multivariate Data Analysis, $4^{\text {th }}$ ed., New Jersey: Prentice Hall, 745 p.

HALL JR. 1970. Description of egg capsules and embryos of the squid, Lolliguncula brevis, from Tampa Bay, Florida. Bull Mar Sci 20: 762-768. 
HUNTER VD AND SimON JL. 1975. Post-cleavage morphology in the squid Lolliguncula brevis (Blainville, 1823). Veliger 18(1): 44-51.

Jereb P, Vecchione M AND Roper CFE. 2010. Family Loliginidae. In: Roper CFE and Jereb P(Eds), Cephalopods of the World: FAO Species Catalogue. Food \& Agriculture Organization, United Nations, Rome, p. 81-83.

KASHIWADA J AND RECKSIEK CW. 1978. Possible morphological indicators of populational structure in the market squid, Loligo opalescens. Calif Fish Game 169: 99-111.

MONTEIRO LR AND REIS SF. 1999. Princípios de morfometria geométrica. FAPESP: Editora Holos, 188 p.

O’DOR RK. 1988. Forces acting on swimming squid. J Exp Biol 137: 421-442.

PANITZ CMN. 1994. Diagnóstico ambiental oceânico e costeiro das regiões sul e sudeste do Brasil. Lagoas costeiras, manguezais, marismas, dunas e restingas, v. 9. Rio de Janeiro: FUNDESPA/PETROBRAS, 413 p.

PereZ JAA AND Haimovici M. 1991. Cephalopod collection of "Museu de Zoologia da Universidade de São Paulo", São Paulo, Brasil. Pap Avulsos Zool 37(16): 251-258.

PIRES-VANIN AMS AND MATSUURA Y. 1993. Estrutura e função do ecossistema de plataforma continental da região de Ubatuba, Estado de São Paulo: uma introdução. Publicação Especial Bol Inst Oceanogr, São Paulo 10: 1-8.

RIOS EC. 1985. Seashells of Brazil. Rio Grande: FURG, 329 p.

ROPER CFE. 1978. Cephalopoda. In: Fisher W (Ed), FAO Species identification sheets for fishery purposes. Western Central Atlantic (Fishing Area 31), Rome, FAO 6: 115-116.
Roper CFE, SWEENEy MJ AND NAUEN CE. 1984. FAO. Species catalogue. Cephalopods of the world: An annotated and illustrated catalogue of species of interest to fisheries, FAO: Fisheries Synopsis 3(125): 277.

ROPER CFE AND VOSS GL. 1983. Guidelines for taxonomic descriptions of cephalopod species. Mem Natl Mus Victoria 44: 49-63.

SIMONE LR. 1997. Redescription of Lolliguncula brevis (Blainville) (Myopsida, Loliginidae) from southeastern Brazil. Iheringia, Ser Zool 82: 141-150.

VECCHIONE M. 1982. Morphology and development of plank tonic Lolliguncula brevis (Cephalopoda: Myopsida). Proc Biol Soc Wash 95: 602-609.

VeCCHIOnE M. 1987. Juvenile ecology. In: Boyle PR (Ed), Cephalopod Life Cycles vol II, Academic Press, p. 61-84.

VECCHIONE M, BRAKONIECKI TF, NATSUKARI Y AND HANLON T. 1998. A provisional generic classification of the family Loliginidae. Smithson Contrib Mar Sci 586: 215-222.

VeCCHIONE M ET AL. 2005. Systematics of Indo-West Pacific Loliginids. Phuket Mar Biol Center Res Bull 66: 23-36.

VOIGHT JR. 1991. Morphological variation in octopod specimens: reassessing the assumption of preservationsinduced deformation. Malacologia 33(1-3): 241-253.

Voss GL. 1956. A review of the Cephalopods of the Gulf of Mexico. Bull Mar Sci Gulf Carib 6(2): 241.

ZAR JH. 1982. Biostatistical Analysis, $3^{\text {rd }}$ ed., Prentice Hall: New Jersey, 662 p. 